\title{
The Problems Experienced in the Integration Process of Syrian Students into the Turkish Education System
}

\author{
Sevilay Şahin, Sabahattin Sümer* \\ Department of Educational Sciences, Gaziantep University, Turkey
}

Copyright $(2018$ by authors, all rights reserved. Authors agree that this article remains permanently open access under the terms of the Creative Commons Attribution License 4.0 International License

\begin{abstract}
This study aimed to determine the problems experienced at schools in the integration process of Syrian students into the Turkish Education System according to 66 school principals from 10 different cities of Turkey. The study was designed with mixed research methodology. According to the research results, there are some problems about the physical condition of schools, the dialogue between Turkish and Syrian students, Syrian students' behaviors at school, the teaching methods of the teachers, administrative processes at school, parent-teacher association, teachers' communication with Syrian students and the supply of guidance services.
\end{abstract}

Keywords Integration, Syrian Refugee Students, School Administrators

\section{Introduction}

Migration is a phenomenon that is closely related with the cultural, economic and political structure of the societies. It is substantial in shaping and changing the social structure [1]. The basic needs such as education, health, and safety of the children, who constitute the most vulnerable social layer among the Syrian refugees, have been interrupted from the very beginning of migration [2]. Education has an important place in each step from the decision of migration to the integration of those who migrated [3], and it may affect the educational decisions of not only those who migrated, but also those who did not migrate as well as those in the hosting countries [4]. Access to education is a basic human right, and is closely related to a better life for children, families, and societies and the economic growth of a country [5]. The educational problems of Syrian refugees have continued to be an important agenda for the hosting countries and international organizations.

Millions of people had to migrate due to the civil war in Syria. Since 2011, the internal disturbances and tensions in Syria exposed Turkey to the waves of migration [6].
Turkey is the country that hosts the most Syrian refugees throughout the world [7]. Turkey has gained the appreciation of international organizations thanks to its hospitality and generosity against the refugees [8]. The number of Syrians who took refuge in Turkey has been increasing since 2011 until today. While the number of refugees in 2012 was 14,237, it reached almost 3 million as of March 2017. In Turkey, the $90 \%$ of Syrian refugees don't prefer to live in temporary refuge centers [8]. Among these people, temporarily protected and recorded biometrically, the number of school-age children (5-18 ages) is over 1 million. The number of Syrian refugees aged between $0-4$ as the potential school-age children is around 360,000 [9]. The researchers indicate that the most vulnerable issue in a civil war is the education of children and teenagers, that the Syrians could not receive education for a while before they migrated to other countries as soon as the war began, and that the education of Syrians has been under difficult conditions in the countries in which they took refuge due to the civil war $[10,11]$.

Turkish Ministry of National Education has carried out a number of initiatives considering the education of Syrians in Turkey since 2011. According to the Human Rights Watch [12], although the Turkish Government generously responded to the refugee crisis, they have difficulty in guaranteeing the right of the Syrian students to be educated. The procedure, beginning with the Temporary Education Centers based on the assumption that the situation in Syria was temporary, resulted in Syrian refugees' registration in state schools due to the ongoing crisis in Syria. In a circular issued in 2010, the Ministry of National Education declared the essentials in the education of foreign students. For the first time, the Ministry of National Education (MEB) attempted to generate solutions for the educational problems of the Syrians institutionally through the circulars and various letters issued on the $26^{\text {th }}$ of April and the $26^{\text {th }}$ of September 2013 [13]. In the letter published on the $26^{\text {th }}$ of April 2013, it was requested to take the necessary precautions though examining the work of the local authorities and non-governmental organizations involved in educational activities as well as the Syrian 
citizens regarding the education of the Syrian children. In the circular issued on the $26^{\text {th }}$ of September 2013, it was indicated that there must be a standard as well as a common action in the implementations regarding the fulfillment of the educational needs of the school-age children accommodated in refuge centers and city centers. In the same circular, it was declared that particularly the teachers who knew Arabic will be employed for the lessons in the refuge centers [14]. In 2014, the first extensive legislative regulation was put into action through issuing the Law on Foreigners and International Protection No. 6458. Thanks to the Temporary Protection Regulation [15] issued with reference to the law, Syrian refugees were granted access to education, health, and social welfare services. In parallel to these extensive legislative regulations, the Ministry of National Education issued a circular of Educational Services for Foreigners on September 2014 [16]. The establishment of a new unit named "the Department of Migration and Emergency Education" within the Directorate General for Lifelong Learning of the Ministry of National Education in 2016 was indeed a significant development for the education of Syrians [17].

As a result of the initiatives of the Ministry of National Education, 230,000 Syrian students started school in 2014-2015 academic year while the number of those who did not have access to education was 451,000 [18]. The number of students attending school reached 496,426 in the 2016-2017 academic year. During that period, while the number of Syrian students attending public school equaled to $16 \%$ of all the students, it increased up to $34 \%$ for the 2015-2016 academic year. It is estimated that the number of students will increase up to 550,000, and the percentage of students attending public schools will be $54 \%$ in the 2016-2017 academic year [19].

The addition of more than 500,000 students to the population will pose new problems for the primary and secondary schools that in need for about 40,000 classrooms and 130,000 teachers [20]. It is stipulated that identifying the problems that are currently experienced and will probably be experienced at schools during the integration process, as well as the suggestions of the school principals considering these problems will benefit to the healthy implementation.

The basic research question of our research is "What are the problems experienced during the integration process of the Syrian students into the Turkish Education System and the solutions offered to them?" The sub-problems of the research are as follows:

What are the problems experienced after the Syrian students are enrolled in public schools due to the physical conditions of the school, the dialogue between Turkish and Syrian students, the conducts of Syrian students at school, teaching methods of teachers, administrative processes at school, parent-teacher association, teachers' communication with Syrian students, the supply of guidance services to Syrian students and Syrian students' inability to speak Turkish?

\section{Materials and Methods}

\subsection{Study Group}

The research was conducted with the 66 school principals at different school levels participated in the "Administrative Staff Contact Meeting" held in Antalya between the $30^{\text {th }}$ of January - the $3^{\text {rd }}$ of February 2017 within the scope of "The Project of Promoting the Integration of Syrian Children into the Turkish Education System" funded by direct grants in areas such as humanitarian aid, education, health, psycho-social support and migration management for "Syrians under Temporary Protection in Turkey" which was initiated by the European Union on October 2016. In order to determine the study group of the research, "maximum variation" sampling method among the purposive sampling methods was used. The main purpose of the sampling method is to reveal the common or different aspects and patterns of various situations that are regarded as consistent with the purpose of the research, and to describe the problem in a broader context [21]. In order to maintain diversity, it was endeavored to reach participants from different school levels and different cities. The study was conducted with 54 male principals and 12 female principals. Based on the school levels, 48 of the participants were at primary schools, 11 of them at secondary schools, and 7 of them at high schools. As the data analysis indicated that the problems encountered were found to be parallel, the results were presented without being diversified according to the school levels. The principals of the study were from 10 different cities namely Batman, Denizli, Gaziantep, Hatay, Kahramanmaraş, Manisa, Mardin, Mersin, Şanlıurfa, and Tekirdağ. The number of Syrian students in the participants' schools varied between 25 and 400 .

\subsection{Data Collection Tool}

A questionnaire with open-ended questions was used in the first stage of this study which was designed with mixed research method. After the literature review [11, 13, 10, 22-25], the draft form of the questionnaire was submitted to the experts and it was finalized with the revisions in line with expert opinions. The questionnaire consisted of the purpose of the questionnaire, personal information, problems observed in the different areas of educational process, and the solutions offered for them. There were 4 questions regarding the demographic information of the participants, and 4 questions regarding the schools in which the participants work. Nine open-ended questions were addressed the participants regarding the potential problems at schools as well as their solution offers about the physical conditions of the school, the dialogue between 
Turkish and Syrian students, Syrian students' behaviors at school, the teaching methods of the teachers, administrative processes at school, parent-teacher association, teachers' communication with Syrian students, the supply of guidance services to Syrian students, and Syrian students' inability to speak Turkish. A separate section was also included in the questionnaire for different problems and solution offers that the participants would like to mention.

\subsection{Data Collection and Analysis}

The questionnaires were administered to 120 participants on a voluntary basis before the start of the meetings in Antalya. It was determined that among 69 of the questionnaires returned, three of them were filled appropriately and the remaining 66 questionnaires were included in the analysis process. The participants were coded as $\mathrm{K} 1, \mathrm{~K} 2, \mathrm{~K} 3 \ldots$

The detailed reporting of the collected data and explaining how the researcher obtained the results are among the most significant criteria for the validation of qualitative research [26]. The data analysis process was explained in detail to ensure the internal validity of the study. In the analysis of the obtained data, the following steps were followed using the "content analysis" technique:

1. Encoding of data

2. Determination of the themes of encoded data

3. Organization of codes and themes

4. Identification and interpretation the findings [26].

The answers given to the open-ended questions in the questionnaires were transcribed and analyzed by means of the software. As a result, the answers for each question were analyzed and grouped independently. In order to ensure the reliability of the study, the obtained data was coded separately by the researchers and the formula of Miles and Huberman [27] (Reliability = consensus $/$ (consensus + dissensus) X 100) was estimated. It was assumed that an adequate level of reliability was maintained since the ratio of consensus was estimated greater than $90 \%$.

\section{Results}

In this section, the findings obtained from the participants were thematized on the basis of the questions and presented together with direct quotations. In accord with the participants' views, the themes were identified as the problems related with the physical condition of the schools, the dialogue between Turkish and Syrian students, Syrian students' behaviors at school, the teaching methods of the teachers, Syrian students' inability to speak Turkish, administrative processes at school, parent-teacher association, teachers' communication with Syrian students and the supply of guidance services. These themes were followed by the suggestions of the school administrators with regard to the problems they identified.

Table 1. The Problems Related with the Physical Condition of the Schools

\begin{tabular}{|c|c|c|}
\hline Theme & Codes & Frequency \\
\hline \multirow{4}{*}{$\begin{array}{c}\text { Physical } \\
\text { Structure }\end{array}$} & Overcrowded classrooms & 21 \\
\cline { 2 - 3 } & Inadequate number of classrooms & 15 \\
\cline { 2 - 3 } & No problem & 15 \\
\cline { 2 - 3 } & Lack of equipment & 4 \\
\cline { 2 - 3 } & Inadequate number of communal areas & 3 \\
\cline { 2 - 3 } & Cleaning & 2 \\
\hline
\end{tabular}

Table 1 showed that certain problems with regard to the physical conditions of the schools arouse together with the registration of Syrian students. The frequencies indicated that "Overcrowded Classrooms" was the biggest problem for the principals and it was followed by "Inadequate Number of Classrooms, Lack of Equipment, Inadequate Number of Communal Areas, and Cleaning" respectively. On the other hand, 15 principals expressed that they did not have any problems with the Physical Condition of their schools. The principals' opinions about the problems related with the physical condition of the schools were as follows: "Much more students were particularly enrolled in the $1^{\text {st }}$ grade. Classes became overcrowded. (K7)", "There has been an increase of 7-8 students in average for each class level... (K22)", "The number of the students in classrooms has increased. The inadequacy of classroom problems has appeared. (K56)", "Classrooms and playgrounds become inadequate. There emerged an accumulation of students in classrooms. (K16)", "Crowded classrooms: Although the storage rooms and laboratories have been converted into classrooms, they are not enough yet. (K13)", "The number of classrooms is insufficient due to the increase in the number of the students. Communal areas are inadequate. (K11)", "...Classrooms are too small. The children sit on the floor. They have no materials. We could only buy a heater by our own means. (K39)", "We did not have any problem about the classrooms. We welcomed them thanks to our tradition of hospitality. We did not have any problems. (K53)", "We do not encounter any problems as school population is not high. (K52)", "There are no classrooms for about 175 students who have been enrolled in the first grade. These students continue their education in the classrooms of a secondary school nearby. (K 21)", "Our school was planned according to the available number of students. For example, the number of our toilets and sinks was not enough. Nearly 100 students enrolled in after the Temporary Education Centers were closed. We built additional toilets \& sinks outside. At first, used a container for that purpose. As they were unhealthy, toilets were built by the governorate. Sinks were built. (K64)" 
Table 2. The Problems Related with the Dialogue between Turkish and Syrian Students

\begin{tabular}{|c|c|c|}
\hline Theme & Codes & Frequency \\
\hline \multirow{4}{*}{$\begin{array}{c}\text { Dialogue } \\
\text { between }\end{array}$} & Language and communication problems & 21 \\
\cline { 2 - 3 } Students & Exclusion & 9 \\
\cline { 2 - 3 } & No problem & 8 \\
\cline { 2 - 3 } & Prejudice & 8 \\
\cline { 2 - 3 } & Cultural differences & 6 \\
\cline { 2 - 3 } & Grouping & 6 \\
\cline { 2 - 3 } & Fighting & 4 \\
\hline
\end{tabular}

When the table was examined, it was clear that the "language and communication problems" took the first place among the dialogue between Turkish and Syrian Students and it was followed by "exclusion, prejudice, cultural differences, grouping, fighting, and integration problems". Eight of the school principals stated that there were no problems between the students. The principals' opinions regarding the issue were as follows: "Syrian students cannot express themselves so there is a lack of communication. (K1)", "The students do not want Syrian students in their classrooms. Syrian students formed groups and do not let the other students in (K9)", "I think the fact that the Syrian students are ill-tempered due to what happened and it leads communication problems. (K16)", "Turkish and Syrian students cannot understand one another due to the language problems. Turkish and Syrian students do not want to be together in the same environment. (K50)", "They isolate Syrians. They are jealous of the aids they get. (K54)", "Turkish students isolate Syrians because of their age. There isn't any socialization due to the language barrier. (K29)", "The children are already very aggressive due to the events in Syria. They are depressed. They start crying when talking to someone. They have no ability to express themselves. They already have language problems. And as we speak Turkish, it is much more difficult for them to express themselves. We permanently deal with these kinds of issues. (K62)",

Table 3. The Problems Related with Syrian Students' Behaviors at School

\begin{tabular}{|c|c|c|}
\hline Theme & Codes & Frequency \\
\hline \multirow{4}{*}{$\begin{array}{c}\text { In-School } \\
\text { Behaviors }\end{array}$} & Absence & 21 \\
\cline { 2 - 3 } & Discipline & 12 \\
\cline { 2 - 3 } & Frequent change of address & 9 \\
\cline { 2 - 3 } & Grouping & 6 \\
\cline { 2 - 3 } & No problem & 4 \\
\cline { 2 - 3 } & High expectations & 2 \\
\cline { 2 - 3 } & Dissatisfaction with the teacher & 6 \\
\hline
\end{tabular}

The table demonstrated that the principals emphasized "absence, disciplinary problems, frequent change of address, grouping, high expectations, and dissatisfaction with the teacher" as the problems related to in-school behaviors. The participants' opinions were as follows: "There may arise disciplinary problems as the children have not fully adopted to school yet and they have been away from school for years (K11)", "The students they have had difficulty in attending to school complying with the disciplinary rules of the school (K9)", "Absenteeism is the major problem with the enrolled students and it stems from moving from one place of residence to another. (K21)", "Syrian students display violent behaviors against each other. They sometimes commit violence on Turkish students. There is no such thing as playing games for them, (K36)", "Our main problems are absenteeism and late arrival after breaks. In addition, they do not listen to the teacher properly during the lessons. (K38), "We have been encountering attendance problems as some Syrian students change their residence. We cannot keep up. (K52)"

Table 4. The Problems Related with the Teaching Methods of the Teachers

\begin{tabular}{|c|c|c|}
\hline Theme & Codes & Frequency \\
\hline \multirow{4}{*}{$\begin{array}{c}\text { Use of } \\
\text { Methods }\end{array}$} & Language problems & 19 \\
\cline { 2 - 3 } & Communication problems & 8 \\
\cline { 2 - 3 } & Lack of methodological knowledge & 3 \\
\cline { 2 - 3 } & No problem & 2 \\
\cline { 2 - 3 } & $\begin{array}{c}\text { Lack of methodology use } \\
\text { Having insufficient knowledge on the } \\
\text { subject }\end{array}$ & 2 \\
\hline
\end{tabular}

In relation to the theme about the teaching methods of the teachers, 19 of the principals referred to language differences. The language problem was followed by "Communication Problems, Teachers' Lack of Methodological Knowledge, Teachers' Lack of Methodology Use, and their Insufficient Knowledge on the Subjects". Two principals pointed out that they did not have any problems. Regarding the issue, the principals' expressions were as follows; "Serious difficulties may arise in terms of education as they use the available techniques and methods and they face with a completely extraordinary phenomenon due to the linguistic difficulties." (K11) "It is difficult for Syrian students to integrate with the class. The methods and techniques are inadequate as the biggest problem is the language problem. (K14)", "Teachers solve the problems through trial and error. (K32)", "Teachers do not know how to teach Turkish. They also think that they will decrease the success rate of the class. (K46)", "It is difficult for the children to understand the subject as they do not know Turkish. (K56)"

Table 5. The Problems Related with Syrian Students' Inability to Speak Turkish

\begin{tabular}{|c|c|c|}
\hline Theme & Codes & Frequency \\
\hline \multirow{4}{*}{$\begin{array}{c}\text { Inability to } \\
\text { Speak } \\
\text { Turkish }\end{array}$} & Language problems & 19 \\
\cline { 2 - 3 } & Lack of communication & 8 \\
\cline { 2 - 3 } & Low achievement level & 6 \\
\cline { 2 - 3 } & Lack of self-expression & 6 \\
\cline { 2 - 3 } & Learning disability & 5 \\
\cline { 2 - 3 } & Delability to complete the curriculum & 4 \\
\cline { 2 - 3 } & Decreasing overall success of the class & 3 \\
\hline
\end{tabular}


The school principals listed the "Language Problems, Lack of Communication Between Teacher and Student, Low Achievement Level, Lack of Self-Expression, Learning Disability, Inability to Complete the Curriculum, Delayed Reading and Writing, and Decreasing Overall Success of the Class" as the problems caused by Syrian students' inability to speak Turkish. Regarding the issue, the principals expressed that; "Problems arise in completing the curriculum on time, and on teachers' reaching the objectives. (K17)", "Teachers spend extra time in communicating these students. It reduces the teacher's time to spend on the other students. (K2)", "As they cannot communicate, they grow up as socially introvert individuals. They have difficulty in learning as they do not know the language. (K11)", "There is a language problem in general. There was also an integration problem due to the cultural conflicts. The curriculum cannot be completed on time due to the language inadequacy. (K21)", "There is a lack of communication between Syrian students and the other students and teachers. (K37)", "It is certain that our Syrian students had difficulty in adapting to the educational environment because of their language deficiencies. There is a problem in communicating with the students. (K52)"

Table 6. The Problems Related with Administrative Processes at School

\begin{tabular}{|c|c|c|}
\hline Theme & Codes & Frequency \\
\hline \multirow{4}{*}{$\begin{array}{c}\text { Administrative } \\
\text { Processes }\end{array}$} & Student recordings & 16 \\
\cline { 2 - 3 } & Inaccuracies in identity cards & 9 \\
\cline { 2 - 3 } & No problem & 5 \\
\cline { 2 - 3 } & Lack of identity cards & 4 \\
\cline { 2 - 3 } & Increased workload & 4 \\
\cline { 2 - 3 } & Lack of communication & 3 \\
\cline { 2 - 3 } & Accreditation procedures & 3 \\
\hline
\end{tabular}

When the principals' opinions regarding the problems in school management processes were examined, it was clear that "Student Recordings" took the first place. It was followed by "Inaccuracies in Temporary Identity Cards, Lack of Identity Cards, Increased Workload, Lack of Communication, and the Problems in Accreditation Procedures" respectively. Five principals stated that they did not have any problems in school's administrative procedures. Regarding the issue, the principals expressed; "Students who do not have an ID number that have been approved by the immigration authority want to enroll in the school. (K9)", "Some students do not have identity cards. There are no documents about in which class they were in their countries. They may leave their registration zone without any notification. (K12)" "There are difficulties in registering the students in our online registration system. The workload of school administration increases. (K18)" "Due to the overloading in the e-school management information system, there are problems about registration. (K28)" "There are problems with the temporary ID numbers. It would be good if the immigration authorities could speed up. (K35)" "Problems may arise about the ID numbers of the students. Sometimes, the registration processes cannot be finished. Some mistakes about the gender of children create problems. (K42)", "There are accreditation problems. We fail to enroll those who do not have a certificate of equivalence. The accreditation procedures were carried out in accord with the age, not the educational level of the child. (K56)", "A 12-year-old Syrian student was sent to the second grade in equivalence without considering his age. In fact, it would be great to take the student's age into consideration during the accreditation procedures. The same student may be accredited for two different grades in two following years. For instance, the student accredited for the second grade, got equivalence for the fourth grade next year. (K60)"

Table 7. The Problems Related with Parent-Teacher Association

\begin{tabular}{|c|c|c|}
\hline Theme & Codes & Frequency \\
\hline \multirow{4}{*}{$\begin{array}{c}\text { Parent-Teacher } \\
\text { Association }\end{array}$} & Lack of communication & 20 \\
\cline { 2 - 3 } & Poor cooperation & 11 \\
\cline { 2 - 3 } & Cultural differences & 5 \\
\cline { 2 - 3 } & $\begin{array}{c}\text { Inability to express the } \\
\text { expectations }\end{array}$ & 6 \\
\cline { 2 - 3 } & Frequent complaints & 2 \\
\hline
\end{tabular}

The school principals mentioned the problems of "Lack of Communication, Poor Cooperation, Cultural Differences, Inability to Express the Expectations, and Frequent Complaints" under the heading of parent-teacher association. Regarding this issue, the principals indicated that; "We have communication problems. The parents do not come to the school often. The cooperation is too weak. (K2)", "We have communication problems with Syrian parents. The majority of the parents do not visit the school after the registration process. (K18)", "As the parents cannot be contacted, the parents of Syrian students are regarded as non-existent. (K28)", "We have linguistic problems with such parents. (K52)", "Their communication skills are inadequate due to language and commitment problems. (K22)", "Cultural differences and language problems are the most important difficulties. (K10)", "The biggest problem with the parents is the language problem. And the biggest problem is that the school is regarded as a place to toss away their children. (K14)"

Table 8. The Problems Related with Teachers' Communication with Syrian Students

\begin{tabular}{|c|c|c|}
\hline Theme & Codes & Frequency \\
\hline \multirow{4}{*}{$\begin{array}{c}\text { Teacher-Student } \\
\text { Communication }\end{array}$} & Language problems & 19 \\
\cline { 2 - 3 } & Communication & 8 \\
\cline { 2 - 3 } & Different attitudes of teachers & 6 \\
\cline { 2 - 3 } & Sense of exclusion & 6 \\
\cline { 2 - 3 } & Grouping & 5 \\
\cline { 2 - 3 } & Cultural differences & 4 \\
\hline
\end{tabular}

The school principals commented on "Language Problems, Communication, Different Attitudes of 
Teachers, Sense of Exclusion, Grouping, and Cultural Differences" with regard to the problems in teachers' communication with Syrian students. Regarding the issue, the principals said that, "Because of the language problem, the teachers have problems in communicating with the students. (K11)", "The biggest problems between the teachers and the Syrian students are communication-related problems (K18)", "As they do not understand the lessons, they get bored, and it leads to disturbances and lack of self-confidence. (K28)", "Teachers are getting more demoralized whenever a new Syrian student comes. Teachers are very demotivated for that reason. (K54)", "There were no problems except the language problem. (K56)", "We did not have any problems. However, if Temporary Education Centers teach only in Arabic, these problems will not come to an end. (K25)", "Teachers, especially the females, have some classroom management problems especially with the older Syrian students. Some teachers have different perspectives. And there are those teachers who are uncomfortable with the Syrians. Of course, the main problem in the classroom arises from the differences in perspectives. Also, the children get bored in the classroom as they have inadequate readiness for that grade. These students will certainly cause troubles for the teacher in classroom management. Teachers have had difficulties in integrating them into the educational processes. (K61)"
Table 9. The Problems Related with the Supply of Guidance Services

\begin{tabular}{|c|c|c|}
\hline Theme & Codes & Frequency \\
\hline \multirow{4}{*}{$\begin{array}{c}\text { Guidance } \\
\text { Services }\end{array}$} & Language problems & 5 \\
\cline { 2 - 3 } & $\begin{array}{c}\text { Inadequate number of } \\
\text { guidance teachers }\end{array}$ & $\begin{array}{c}\text { Misbehaviors of the } \\
\text { students }\end{array}$ \\
\cline { 2 - 3 } & Cultural differences & 3 \\
\cline { 2 - 3 } & $\begin{array}{c}\text { Inadequate guidance } \\
\text { services }\end{array}$ & 6 \\
\hline
\end{tabular}

The school principals indicated "Language Problems, Inadequate Number of Guidance Teachers, Misbehaviors of the Students, Cultural Differences, and Inadequate Guidance Services" with regard to the problems about the supply of guidance services. Regarding the issue, the principals expressed that; "Since there is no guidance teacher in our school, elementary teachers deal with this issue. The guidance services are inadequate. (K11)", "In the provision of guidance services, language and communication problems prevent them to be effective. (K18)", "There is only one guidance teacher in the school with a very problematic profile of 480 students. When Syrian students were enrolled, the problems increased and the teacher became incapable. (K14)", "The guidance services are inadequate. (K22)", "There is no such guidance activity yet. (K32)"

Table 10. The Suggestions of the School Administrators with regard to the identified Problems

\begin{tabular}{|c|c|}
\hline Problems & Suggestions \\
\hline $\begin{array}{l}\text { The Problems Related with the } \\
\text { Physical Condition of the } \\
\text { Schools }\end{array}$ & $\begin{array}{l}\text { Building additional classrooms (21) } \\
\text { Providing financial support for schools (6) } \\
\text { Changing of laboratories and workshops into classrooms (2) } \\
\text { Balanced distribution of students to schools (2) }\end{array}$ \\
\hline $\begin{array}{l}\text { The Problems Related with the } \\
\text { Dialogue between Turkish and } \\
\text { Syrian Students }\end{array}$ & $\begin{array}{l}\text { Teaching the students Turkish before starting education at schools (12) } \\
\text { Holding contact meetings with the families regarding the functioning of schools in Turkey (10) } \\
\text { Carrying out inclusion studies at schools (6) } \\
\text { Improving the guidance works at schools (5) } \\
\text { Considering the cultural differences in school activities (5) } \\
\text { Employing Arabic-speaking staff at schools (4) } \\
\text { Providing the teachers with on-the-job training (2) } \\
\text { The problems will be relieved in time (3) }\end{array}$ \\
\hline $\begin{array}{l}\text { The Problems Related with } \\
\text { Syrian Students' Behaviors at } \\
\text { School }\end{array}$ & $\begin{array}{l}\text { Organizing the family trainings (11) } \\
\text { Providing in-kind and in-cash aid on the condition of compulsory attendance (6) } \\
\text { Updating the address and contact details of the students (6) } \\
\text { Providing compulsory Turkish language preparation course for the students (6) } \\
\text { Utilizing the guidance services at schools more actively (4) } \\
\text { Placing the Syrians in permanent houses (3) } \\
\text { Making home visits to students (3) } \\
\text { Recording the internal migration of the Syrians within Turkey (3) } \\
\text { Employing Arabic-speaking staff at schools (3) } \\
\text { Imposing penal sanctions (2) } \\
\text { The problems will be relieved in time (3) }\end{array}$ \\
\hline $\begin{array}{l}\text { The Problems Related with the } \\
\text { Teaching Methods of the } \\
\text { Teachers }\end{array}$ & $\begin{array}{l}\text { Teaching Turkish to the students before accepting into school (13) } \\
\text { Providing the teachers with on-the-job training regarding the education of foreign students (6) } \\
\text { Employing Arabic-speaking staff at schools (4) } \\
\text { Teaching Arabic and Kurdish to the teachers (4) } \\
\text { Utilizing the guidance services more actively (2) }\end{array}$ \\
\hline
\end{tabular}




\begin{tabular}{|c|c|}
\hline $\begin{array}{l}\text { The Problems Related with } \\
\text { Syrian Students' Inability to } \\
\text { Speak Turkish }\end{array}$ & $\begin{array}{l}\text { Giving extra courses to the students especially in Turkish (7) } \\
\text { Employing Arabic-speaking staff at schools (4) } \\
\text { Providing pre-school education to the students necessarily (3) } \\
\text { Providing on-the-job training to the teachers (2) } \\
\text { Increasing the weekly hours of Turkish lessons (2) } \\
\text { Placing the Syrian students who do not speak Turkish next to the Syrian students speaking Turkish } \\
\text { (2) }\end{array}$ \\
\hline $\begin{array}{l}\text { The Problems Related with } \\
\text { Administrative Processes at } \\
\text { School }\end{array}$ & $\begin{array}{l}\text { Updating the official records of the Syrians (4) } \\
\text { Coordination of the governmental agencies (4) } \\
\text { The relevant institutions' paying attention to the registrations (3) } \\
\text { Issuing documents immediately for the Syrians who do not have a temporary ID (3) } \\
\text { Registering the Syrians in the Central Civil Registration System (2) } \\
\text { Simplifying the student registration system (2) } \\
\text { Taking the age of the students into consideration when nostrificating (2) } \\
\text { Informing the Syrian parents about the registration areas and periods of the schools (2) }\end{array}$ \\
\hline $\begin{array}{l}\text { The Problems Related with } \\
\text { Parent-Teacher Association }\end{array}$ & $\begin{array}{l}\text { Opening Turkish courses for the parents (11) } \\
\text { Employing Arabic-speaking staff at schools (8) } \\
\text { Providing family training for the Syrian parents (5) } \\
\text { Paying home visits (4) } \\
\text { Establishing an office regarding the Syrian students at schools (3) } \\
\text { Providing financial aid to the parents (2) }\end{array}$ \\
\hline $\begin{array}{l}\text { The Problems Related with } \\
\text { Teachers' Communication } \\
\text { with Syrian Students }\end{array}$ & $\begin{array}{l}\text { Teaching Turkish to the students before they accepting into schools (10) } \\
\text { Making use of games (5) } \\
\text { Maintaining effective communication with the students (2) } \\
\text { Placing the Syrian students in different classes (2) } \\
\text { Increasing values education (2) }\end{array}$ \\
\hline $\begin{array}{l}\text { The Problems Related with the } \\
\text { Supply of Guidance Services }\end{array}$ & $\begin{array}{l}\text { Starting the guidance services for Syrians immediately (5) } \\
\text { Improving the guidance works at schools (3) } \\
\text { Employing Arabic-speaking staff at schools (3) } \\
\text { Placing the female students in the classrooms of female teachers (2) } \\
\text { Taking the cultural differences into account at schools (2) } \\
\text { Providing the guidance teachers with on-the-job training regarding the communication with } \\
\text { foreign students (2) } \\
\text { Assigning a psychologist to each area of education (1) }\end{array}$ \\
\hline
\end{tabular}

In Table 10, the recommendations of school administrators with regard to the problems they identified were submitted. When the findings were examined, it was observed that the students' being taught Turkish before starting the educational process was at the first rank and it was followed by assigning Arabic-speaking staff to schools, the construction of additional classrooms, the enhancement of inclusion and guidance works, the organization of family trainings, the opening of Turkish language courses for the parents, informing the families regarding the functioning of schools in Turkey, visiting the students at home, giving additional training to students, giving financial support to schools, keeping the students' address and contact information up-to-date. Among the aforementioned recommendations, it was observed that the students' being taught Turkish before starting the educational process, assigning Arabic-speaking staff to schools, the organization of family trainings and more effective implementation of guidance services were suggested for a number of problems.

\section{Results}

The research results obtained from 66 experienced school principals indicate that there are potential problematic areas at schools during the integration of Syrian students into the Turkish Education System. The school principals pointed out overcrowded classrooms as one of the most important problems in the physical condition of the schools. Similarly, other researchers [28-30] were determined to emphasize the same issue. The overcrowded classrooms were also included in the annual reports published by Eğitim-İş [31] and Eğitim Bir-Sen [32]. The previous studies $[33,34,20]$ also addressed the problem of insufficient number of classrooms which was mentioned by the school principals as another problem. Moreover the findings related to the lack of equipment are in line with the findings of Semerci \& Çelik [34], Kösterelioğlu \& Bayar [35], Sencer [36], Yılmaz \& Altınkurt [28]. Based on these findings, it can be alleged that the problems related to the physical condition of the schools have increased even more with the arrival of the Syrian students.

The problems between the Turkish and Syrian students were specified as the language and communication problems, exclusion, prejudice, cultural differences, grouping, fighting, and integration problems. The findings related to the language $\&$ communication problems and integration problems are in line with the findings of the 
study conducted by Şeker \& Sirkeci [37], Mercan Uzun \& Bütün [38], and Roher \& Sweet [39]. In their research regarding the Temporary Education Centers, Balkar, Şahin, and Işıklı Babahan [40], stated that there were integration problems between the Syrian and Turkish students inside and outside the school.

Attendance, discipline, frequent change of address, grouping, high expectations, and dissatisfaction with the teacher were determined as the problems related to the in-school behaviors of the Syrian students. The findings regarding discipline and absenteeism problems were also emphasized by İmamoğlu and Çalışkan [41].

The problems related with the teaching methods of the teachers were listed as the language problems, communication problems, lack of methodological knowledge, lack of methodology use, and having insufficient knowledge on the subject. Similarly, the fact that the available teachers do not have sufficient information about the education of refugee students was also extrapolated in the research conducted by the United Nations Refugee Agency [42] and Sirin \& Rogers-Sirin [43]. In their study on the teachers having foreign students in their classes, Ciğerci and Güngör [44] concluded that the language problems that make it difficult to express themselves caused communication and comprehension problems.

The participants revealed the language problems, lack of communication, low achievement level, lack of self-expression, learning disability, inability to complete the curriculum, delayed reading and writing, and a decrease in the overall success of the class as the problems caused by Syrian students' inability to speak Turkish. Cochran [45] states that after a few years away from school, the Syrian students failed to cope with the problems associated with the curriculum, language, and school. It is argued that citizens of the immigrant-receiving countries are afraid that the immigrant children may reduce the quality of education of their children, that teaching the immigrant and local students together may slow down the teaching speed, and that it may decrease the expectations of the teachers from all students [46].

The school principals mentioned: student recordings, inaccuracies in identity cards, lack of identity card, increased workload, lack of communication, and accreditation procedures about the problems in administrative processes at school. The problems experienced during the registration of the first-arriving Syrians due to the "open door policy" [47] that Turkey imposed on Syrian refugees also caused problems during the enrollment procedures in education. The Ministry of National Education started to use the Foreign Students Information Operation System (YÖBİS) in 2014 in order to solve the problems related to the enrollment of the Syrian [48]. Subsequently, the Ministry of National Education included the foreign students in the e-school system as well.

The participants stated lack of communication, poor cooperation, cultural differences, inability to fully express the expectations, and frequent complaints among the problems related with parent-teacher association as the most important stakeholders of the school. Fazily [49] indicates that many refugee parents have difficulty in communicating with the school personnel and the other parents due to the language-related problems. Şeker and Sirkeci [37] suggested similar findings on the indifference of Syrian parents about the school. On the contrary, Balkar, Şahin and Işıklı Babahan [40] expressed that Syrian parents had positive attitudes towards the cooperation with the school. The differences between the findings may be attributed to the fact that the research carried out by Balkar et. al. [40] included mostly the Syrian teachers in the Temporary Education Centers.

The language problems, communication, different attitudes of teachers, sense of exclusion, grouping, and cultural differences become prominent among the problems related with teachers' communication with Syrian students. Similar findings were obtained from the research conducted by Sarıtaş, Şahin and Çatalbaş [50] as well as İmamoğlu and Çalışkan [41].

The problems related with the supply of guidance services were determined as language problems, inadequate number of guidance teachers, misbehaviors of the students, cultural differences, and inadequate guidance services. The traumas and losses of many Syrians having fled from the war [43] make it much more necessary for the schools to provide guidance services to these students more often.

In order to solve these problems, school principals suggested the addition of classrooms and the conversion of laboratories \& workshops into classrooms to alleviate the problem of overcrowded classrooms. The suggestions of the participants are similar to the solution offers of Cerit, Akgün, Yıldız and Soysal [51] for the problems encountered in the implementation of the newer education system. For the problems related to the student registrations, the school principals suggested updating the official records of the Syrians, coordination of the governmental agencies, solving the problems related to the temporary identity cards, distributing the students to schools in a balanced manner, and considering the age of the students in nostrificating. For the problems related to parent-teacher association and Syrian students, the participants offered educating the teachers, paying home visits, employing Arabic-speaking staff at schools, providing language education with the students and the parents, raising the awareness of the parents, providing the teachers with on-the-job training, and conducting integration works. The brochure in the UK [52] on what to do to become a refugee-friendly school includes similar suggestions to the above-mentioned solution offers, such as Initiating the Integration and Utilizing the Other Children's Abilities, Creating a Climate Where the Refugee Children Will Be Welcomed and Feel Themselves Valued.

As a result, it is concluded that there are various 
problems from the physical environment to the educational processes during the integration of Syrian students into the Turkish Education System. The uncertainties related to the solution of the problems in Syria require the development of more comprehensive and long-term policies addressing the Syrian students in Turkey. In addition to the participants' suggestions, the following implications can be offered as well:

1. Necessary precautions should be taken to enable the Syrian students to access pre-school education for the prevention of the problems that may arise in schooling.

2. From the perspective that education cannot be independent from the family, family trainings should be organized for the Syrian parents.

3. To make healthier plans for the Syrians, a population registration-tracking system similar to the Central Civil Registration System should be established.

4. Additional trainings within the scope of Support and Education Courses should be provided with Syrian students whose academic achievement levels are below the class average.

5. More resources should be allocated from national and international funds for these students as well as for the schools they attend.

\section{REFERENCES}

[1] G. Gerşil, R. Temel. Türkiye'de Suriyeli sığınmacıların çalışma koşulları ve enformel istihdamı, Turkish Migration Conferance 2016, London, England, 2016

[2] B. D. Çatak. Temporary Education Centers as a temporary solution for educational problems of Syrian refugee children: case of Mersin, Turkish Migration Conferance 2016, London, England, 2016

[3] A. F. Yaylac1, F. G. Yaylac1. Migration and Education Studies in Turkey: A General Evaluation, Turkish Migration Conferance 2016, London, England, 2016

[4] C. Dustmann, A. Glitz. Migration and Eduaction, Handbook of the Economics Education Norface Migration Discussion Paper, 2011, Vol.5, No.2011-11

[5] S. Dryden-Peterson. Refugee Education, A Global Review. UNHCR Policy Develepment and Education Service, Switzerland. 2011

[6] TEDMEM. 2015 Eğitim Değerlendirme Raporu. Ankara: Türk Eğitim Derneği, 2015

[7] J. Bubbers. Beyond aid: educating Syria's refugees, Online available from https://www.britishcouncil.org/organisation/policy-insightresearch/insight/beyond-aid-educating-Syrias-refugees

[8] Birleşmiş Milletler Dergisi. Birleşmiş Milletler ve ortakları Türkiye'deki Suriyeli mülteciler ve ev sahibi topluluklar için yeni bir fon çağrısında bulunuyor, Online available from

http://www.bmdergi.org/language/tr/birlesmis-milletler-ve- ortaklari-turkiyedeki-suriyeli-multeciler-ve-ev-sahibi-toplu luklar-icin-yeni-bir-fon-cagrisinda-bulunuyor

[9] Göç İdaresi Genel Müdürlüğü. Geçici Koruma Kapsamindaki Suriyeliler, Online available from http://www.goc.gov.tr/icerik6/gecici-koruma_363_378_47 13 icerik

[10] A.R. Seydi. Türkiye'deki Suriyeli Akademisyen ve Eğitimcilerin Görüşlerine Göre Suriye'deki Çatışmaların Suriyelilerin Eğitim Sürecine Yansımaları, SDÜ Fen Edebiyat Fakültesi Sosyal Bilimler Dergisi, No.30, 217-241, 2013

[11] A.R. Seydi. Türkiye'nin Suriyeli Sığınmacıların Eğitim Sorununun Çözümüne Yönelik İzlediği Politikalar, SDÜ Fen Edebiyat Fakültesi Sosyal Bilimler Dergisi, No.31, 267-305, 2014

[12] Human Rights Watch. Türkiye: 400000 Suriyeli Çocuk Okula Gitmiyor, Online available from https://www.hrw.org/tr/news/2015/11/08/283225

[13] M.N. Emin. Türkiye'deki Suriyeli Çocukların Eğitimi Temel Eğitim Politikaları, Online available from http://file.setav.org/Files/Pdf/20160309195808 turkiyedek i-suriyeli-cocuklarin-egitimi-pdf.pdf

[14] MEB. Ülkemizde Kamp Dışında Misafir Edilen Suriye Vatandaşlarına Yönelik Tedbirler, Online available from http://melikgazi.meb.gov.tr/meb_iys_dosyalar/2013_05/03 024558 suriye.pdf

[15] Göç İdaresi Genel Müdürlüğü. Geçici Koruma Yönetmeliği, Online available from http://www.goc.gov.tr/files/files/03052014_6883.pdf

[16] MEB. Yabancılara Yönelik Eğitim-Öğretim Hizmetleri, Online available from

http://mevzuat.meb.gov.tr/html/yabyonegiogr_1/yabyonegi ogr_1.html

[17] İ, Coşkun,. N. Dama, M.N. Emin,. D.Toklucu, M.Barkçin, 2016 ' da Eğitim ve Sosyal Politikalar, Online available from http://setav.org/assets/uploads/2017/01/2016Egitim.pdf.

[18] UNICEF. Türkiye' deki Suriyeli Çocuklar, Online available from

http://unicef.org.tr/files/bilgimerkezi/doc/T\%C3\%BCrkiye deki\%20Suriyeli\%20\%C3\%87ocuklar Bilgi\%20Notu\%20 Kasim\%202015.pdf

[19] SETAV. Suriyeli Çocukların Yıllara Göre Eğitim Veriler ve Okullaşma Oranları, Online available from $\mathrm{http}: / /$ www.setav.org/suriyeli-cocuklarin-yillara-gore-egiti $\mathrm{m}$-verileri-ve-okullasma-oranlari

[20] Eğitim Bir-Sen. Eğitime Bakış 2016 İzleme ve Değerlendirme Raporu, Ankara, 2016

[21] Ş. Büyüköztürk, E. K1lıç-Çakmak, Ö. E. Akgün, Ş. Karadeniz, F. Demirel. Bilimsel Araştırma Yöntemleri, Pegem Akademi Yayıncılık, Ankara, 2010

[22] A. Hanna. Türkiye'deki Suriyeli Mültecilerin Eğitim Sorunu, Online available from https://www.al-monitor.com/pulse/tr/originals/2016/11/syr ia-education-schools-turkey-radicalism.html

[23] E. Yıldırım. Suriyeli Mültecilerin Eğitimi ve Entegrasyonu, Online available from 
http://insamer.com/tr/suriyeli-multecilerin-egitimi-ve-ente grasyonu_309.html

[24] Y. Y. Özer, A. Komsuoğlu, Z. Ö. Ateşok. Türkiye'deki Suriyeli Cocukların Eğitimi: Sorunlar ve Çözüm Önerileri, online available from http:/www.asosjournal.com/Makaleler/913122809_a.pdf

[25] İ. Coşkun, ve M. N. Emin, Türkiye'deki Suriyelilerin Eğitiminde Yol Haritası, Seta Yayınları, İstanbul, 2016

[26] A. Yıldırım, H. Simsek. Sosyal Bilimlerde Nitel Arastırma Yöntemleri, Seçkin Yayıncıllk, Ankara, 2011

[27] M. B. Miles, A. M. Huberman. Qualitative Data Analysis: An Expanded Sourcebook, Sage Publications, California, 1994

[28] K. Yılmaz, Y. Altınkurt. Öğretmen Adaylarının Türk Eğitim Sisteminin Sorunlarına İlişkin Görüşleri, Uluslararas1 İnsan Bilimleri Dergisi, Vol.:8 No.1 ,942-973

[29] F. Akın, O. Şimşek, T. Erdem. Türkiye'de Eğitim Sorunu Toplumsal Aktörlerine Göre Eğitim Sorunlarına Bakış, Türk Eğitim-Sen, Ankara, 2007

[30] H. Demirtaş, M. Üstüner, N. Özer. Okul Yönetiminde Karşılaşılan Sorunların Öğrenci ve Okul ile İlgili Değişkenler Açısından İncelenmesi, Kuram ve Uygulamada Eğitim Yönetimi, No.51, 421-455

[31] Eğitim-İ̧. 2016-2017 Eğitim Öğretim Y1lı Değerlendirme Raporu, Eğitim ve Bilim İşgörenleri Sendikası Genel Merkezi, Ankara, 2017

[32] Eğitim-Bir-Sen. Tam Gün Eğitim İçin Ne Kadar Yeni Dersliğe İhtiyaç Var?, Eğitime Bakış Notu 1, EBSAM Eğitim-Bir-Sen Stratejik Araştırmalar Merkezi, Ankara, 2016

[33] A. Akbaba, M. Turhan. İlköğretim Okul Binalarının Fiziksel Sorunlarına İlişkin Öğretmen Görüşlerinin İncelenmesi(Van İl Örneği). Karadeniz Teknik Üniversitesi Sosyal Bilimler Enstitüsü Dergisi, No.12.

[34] N. Semerci, V. Çelik, İlköğretimde Problemler ve Çözüm Yolları, Kuram ve Uygulamada Eğitim Yönetimi, No.30, 205-221.

[35] İ. .Kösterelioğlu, A.Bayar. Türk Eğitim Sisteminin Sorunlarına İlișkin Güncel Bir Değerlendirme, The Journal of Academic Social Science Studies, No.25-I, 177-187

[36] M. Sencer. Eğitim Sorunları, Amme İdaresi Dergisi, No.8, 9-36

[37] B.D. Şeker, İ. Sirkeci. Challenges for Refugee Children at School in Eastern Turkey, Economics and Sociology, Vol.8, No 4, 122-133

[38] E. Mercan Uzun, E .Bütün. Okul Öncesi Eğitim Kurumlarındaki Suriyeli Sığınmacı Çocukların Karşılaştıkları Sorunlar Hakkında Öğretmen Görüşleri, Uluslararası Erken Çocukluk Eğitimi Çalışmaları Dergisi, Vol.1, No.1, 72-83

[39] E.M. Roher, S. Sweet. An Educator's Guide To Welcoming
Syrian Refugee Children, Online available from http://blg.com/en/News-And-Publications/Publication_437

[40] B. Balkar, S. Şahin, N. Işıklı Babahan. Problems Confronted By Syrian Teachers Working at Temporary Education Centers(TECs), Journal of Theory and Practise in Education, Vol.12, No.6, 1290-1310

[41] H.V. İmamoğlu, E. Çalışkan, Yabancı Uyruklu Öğrencilerin Devlet Okullarında İlkokul Eğitimine Dair Öğretmen Görüşleri: Sinop İli Örneği, Karabük Üniversitesi Sosyal Bilimler Dergisi, Vol. 7, No.2, 529-546

[42] UNHCR. 5 challenges to accessing education for Syrian refugee children Online available from http://www.unhcr.org/innovation/5-challenges-to-accessin g-education-for-syrian-refugee-children/

[43] S.R. Sirin, L. Rogers-Sirin. The Educational and Mental Health Needs of Syrian Refugee Children, Migration Policy Institute, Washington DC, 2015

[44] F.M. Ciğerci, F. Güngör. The Problems Encountered by the Foreign Primary School Students from the Perspectives of Classroom Teachers (Bilecik Sampling), Journal of Education and Future, No.10, 137-164.

[45] J. Cochran. The Education of Syrian Refugee Children, Online available from

http://www.mei.edu/content/at/education-syrian-refugee-ch ildren

[46] J. Hunt. The impact of immigration on the educational attainment of natives, Online available from $\mathrm{http}: / /$ voxeu.org/article/impact-immigration-educational-att ainment-natives

[47] Dışişleri Bakanlığı. Türkiye'nin Bazı Suriyelileri Zorla Ülkelerine Gönderdiği İddiaları Hk., Online available from http://www.mfa.gov.tr/no_-83_-3-nisan-2016_turkiye_nin -bazi-suriyelileri-zorla-ulkelerine-geri-gonderdigi-iddialari -hk_.tr.mfa

[48] Hürriyet Gazetesi. Suriyeli öğrencilere "tek tuşla" ulaşılacak, Online available from $\mathrm{http}: / / w w w . h u r r i y e t . c o m . t r / s u r i y e l i-o g r e n c i l e r e-t e k-t u s l a-u$ lasilacak-27593775

[49] F. Fazily. The Perception of Teachers and Refugee Parents Regarding Refugee Children's Education: A Parent Involvement Study, Education Doctoral. Paper 22.

[50] E. Sarıtaş, Ü. Şahin, G. Çatalbaş. İlkokullarda Yabancı Uyruklu Ögrencilerle Karşılaşılan Sorunlar. Pamukkale Üniversitesi, Sosyal Bilimler Enstitüsü Dergisi, No.25/1, 208-229

[51] Y. Cerit, N. .Akgün, K. Yıldız, M. R. Soysal. Yeni Eğitim Sisteminin $(4+4+4)$ Uygulanmasında Yaşanan Sorunlar ve Çözüm Önerileri (Bolu İl Örneği), Eğitim Bilimleri Araştırmaları Dergisi, Vol.4 Özel Sayı:1, 59-82

[52] National Union of Teachers. Welcoming Refugee Children to Your School, Online available from https://www.teachers.org.uk/sites/default/files2014/refugee -teaching-guide-web--10248-.pdf 